\title{
Strengthening the Value of Religious Moderation in Islamic Boarding Schools
}

Received: 20-10-2021

Revised: 28-12-2021

Accepted: 14-01-2022

\author{
Zakariyah $^{1}$, Umu Fauziyah ${ }^{2}$, Muhammad Maulana Nur Kholis ${ }^{3}$ \\ Universitas Islam Negeri Sunan Ampel Surabaya, Indonesia \\ Institut Pesantren Kh. Abdul Chalim, Pacet Mojokerto, Indonesia \\ Universitas Al-Azhar Chairo, Egypt \\ Email: zakariyah@gmail.com
}

\begin{tabular}{l}
\hline Keywords: \\
Moderation \\
Values, Islamic \\
Education, \\
Islamic Boarding \\
Schools, \\
Education \\
Implementation \\
\hline
\end{tabular}

Kata kunci: Nilai

Moderasi,

Pendidikan Islam,

Pesantren,

Implementasi

Pendidikan

\begin{abstract}
This article aims to describe and determine the value of moderation and the implementation of the value of moderation in Islamic education at the Al-Fattah Siman Islamic Boarding School Sekaran Lamongan. This article uses a descriptive qualitative research design. The study's data collection methods were interviews, observation, and documentation studies. Data were analyzed using descriptive analysis. The results of the research on the implementation of moderation values in Islamic education at the Al-Fattah Siman Islamic Boarding School Sekaran Lamongan show that; 1) Understanding the values of moderation in Islamic education is the basis for the formation of the character of the santri who in practice adheres to the principles of Ahlussunnah waljama'ah understanding with a tendency to moderation or wasatiyyah through understanding Aqedah, sharia. or worship and morality. 2) The implementation of moderation values in Islamic education is carried out in several stages, namely planning, implementation and evaluation. 3) The implementation of the values of moderation in Islamic education at the Al-Fattah Siman Islamic Boarding School Sekaran Lamongan is applied to three activities, namely teaching and learning activities, religious-spiritual activities, and skills supporting activities; 4) The implementation of moderate values in Islamic education uses four strategies, namely introduction, habituation, example, and practice; 5) Evaluation of the implementation of moderation values in Islamic education is divided into three forms, namely program evaluation, evaluation of the learning process and evaluation of learning outcomes.
\end{abstract}




\begin{tabular}{l}
\hline Hasil penelitian implementasi nilai-nilai moderasi pada pendidikan Islam di \\
Pondok Pesantren Al-Fattah Siman Sekaran Lamongan menunjukkan \\
bahwa; 1) Pemahaman nilai-nilai moderasi menjadi dasar dalam \\
pembentukan karakter santri yang pada pelaksanaannya berpegang teguh \\
pada prinsip-prinsip paham ahlussunnah waljama'ah dengan tendensinya \\
pada moderasi atau wasatityyah melalui pemahaman aqidah, syariah atau \\
ibadah dan akhlak. 2) Implementasi nilai-nilai moderasi dilakukan dalam \\
beberapa tahap yaitu perencanaan, pelaksanaan dan evaluasi. 3) \\
Pelaksanaan implementasi nilai-nilai moderasi diterapkan pada tiga \\
kegiatan yaitu dalam kegiatan belajar mengajar, kegiatan spiritual \\
keagamaan dan kegiatan penunjang ketrampilan; 4) Pelaksanaan \\
implementasi nilai-nilai moderasi menggunakan empat strategi yaitu \\
pengenalan, pembiasaan, keteladanan, dan pengamalan; 5) Evaluasi \\
implementasi nilai-nilai moderasi terbagi menjadi tiga bentuk yaitu \\
evaluasi program, evaluasi proses pembelajaran dan evaluasi hasil belajar. \\
\hline
\end{tabular}

\section{INTRODUCTION}

In recent years, Indonesia has raised radicalism, extremism, terrorism, and the Khilafah State. As happened in the 2018, 2019, and 2020 elections, all parts of this nation face religious problems deliberately created by certain Islamic groups ${ }^{1}$. The group wants to use religion and divide Muslims for political gain. The government constantly socializes religious moderation to prevent divisions between religious communities ${ }^{2}$.

In the millennial era, through social media as propaganda to gain sympathy, the development of terrorism and radicalism is relatively rapid ${ }^{3}$. By using the internet or online media, they make young people radical like the findings of Brian Levin that happened in America. From the results of his research, it is of strategic value in this millennial era, related to technological developments to strengthen the statement that online media can control a situation ${ }^{4}$.

\footnotetext{
1 Agus Adi, Maya Sari, and Rr Setyowati, 'Radicalism and Political Indentity in Indonesia President Election 2019' (International Conference on Social Science 2019 (ICSS 2019), Atlantis Press, 2019), 411-16, https://doi.org/10.2991/icss-19.2019.161; Edward Aspinall and Marcus Mietzner, 'Southeast Asia's Troubling Elections: Nondemocratic Pluralism in Indonesia', Journal of Democracy 30, no. 4 (2019): 104-18, https://doi.org/10.1353/jod.2019.0055.

2 Robert W. Hefner, 'Islamic Radicalism in a Democratizing Indonesia', in Routledge Handbook of Political Islam (Routledge, 2011).

3 Iffatin Nur et al., 'Embracing Radicalism and Extremism in Indonesia with the Beauty of Islam', Asian Research Journal of Arts \& Social Sciences, 31 January 2020, 1-18, https://doi.org/10.9734/arjass/2020/v10i230141.

4 Brian Levin and John David Reitzel, 'Report to the Nation: Hate Crimes Rise in U.S. Cities and Counties in Time of Division and Foreign Interference', 2018, https://ncvc.dspacedirect.org/handle/20.500.11990/975.
} 
The term wasa'iyyah is interpreted the same as moderation. It is not new in Islam. Muslims recognize that moderation or wasa'iyyah is something important because of moderation ${ }^{5}$. This moderation hints at the characteristics of Muslims, such as the word of Allah SWT in the Qur'an.

Al-Qur'an and Al-Hadith become the primary sources of Islamic teachings instructing Muslims to create progress in their lives and prosper their lives in society, increasing the dignity and status of individuals and socially both in life in the community. World or in the hereafter ${ }^{6}$. The Qur'an is the source and guide of human life in carrying out all life activities, including religious moderation?

The Qur'an views moderation as the core of social life with the term khayra ummah. The Qur'an calls moderation wasa'iyyah. Moderation must be understood as a collective consensus to maintain a balanced wholeness in society. Every community member must be willing to accept each other's opinions regardless of race, ethnicity, ethnicity, religion, culture, and political choices try to train to cultivate existing differences ${ }^{8}$.

Issues of terrorism, extremism, and radicalism are often associated with the world of Islamic boarding schools. In Indonesia, Islamic boarding schools have become icons of Islamic educational foundations that provide tangible evidence to educate and teach indigenous people to become a society with good morals9. Until now, the debate about radicalism in Islamic boarding schools still often appears and becomes a hot discussion in the public sphere, causing unrest in society. However, it cannot be generalized that all pesantren (Islamic Boarding School) are adherents of

\footnotetext{
${ }^{5}$ Wan Kamal Mujani, Ermy Azziaty Rozali, and Nor Jamaniah Zakaria, 'The Wasatiyyah (Moderation) Concept: Its Implementation In Malaysia', Mediterranean Journal of Social Sciences, 1 July 2015, https://doi.org/10.5901/mjss.2015.v6n4s2p66; Mazlan Ibrahim et al., 'Wasatiyyah Discourse According to Muslim Scholars in Malaysia', 2013, 9.

6 M. Arifin, Ilmu Pendidikan Islam: Suatu Tinjauan Teoritis dan Praktis Berdasarkan Pendekatan Interdisipliner (Bumi Aksara, 1991).

7 Siti Yumnah, 'Construction of Islamic Boarding Shcool in Developing Moderate Islam', Nazhruna: Jurnal Pendidikan Islam 3, no. 2 (24 July 2020): 232-46, https://doi.org/10.31538/nzh.v3i2.614; Betria Zarpina Yanti and Doli Witro, 'Islamic Moderation as A Resolution of Different Conflicts of Religion', Andragogi: Jurnal Diklat Teknis Pendidikan Dan Keagamaan 8, no. 1 (16 July 2020): 446-57, https://doi.org/10.36052/andragogi.v8i1.127.

8 Fauziah Nurdin, 'Moderasi Beragama menurut Al-Qur'an dan Hadist', Jurnal Ilmiah Al-Mu'ashirah: Media Kajian Al-Qur'an dan Al-Hadits Multi Perspektif 18, no. 1 (30 January 2021): 59-70, https://doi.org/10.22373/jim.v18i1.10525.

9 Abdul Malik, Ajat Sudrajat, and Farida Hanum, 'Kultur Pendidikan Pesantren Dan Radikalisme', Jurnal Pembangunan Pendidikan: Fondasi dan Aplikasi 4, no. 2 (2016): 103-14, https://doi.org/10.21831/jppfa.v4i2.11279.
} 
radical and extremist religions ${ }^{10}$. Some Kiai (Leader of Islamic Boarding School) or founders of Islamic boarding schools foster and educate their students to become a militant generation in their religious appreciation and more modern and moderate in their religious appreciation ${ }^{11}$.

In addition to the distinctive character of Indonesia, pesantren continuously transmits an understanding of religious understanding that is tolerant, peaceful, non-radical, and respectful of each other. Not close to terrorism, especially justifying suicide bombings ${ }^{12}$. In a pluralistic Indonesian society, Islamic boarding schools have a strategic role. Islamic boarding schools can spread religion, uphold peaceful and tolerant national values. Islamic boarding schools adapt to differences and diversity in society ${ }^{13}$. Therefore, it is natural that Islamic boarding schools become the leading guardians in developing the Islamic understanding of Rahmatalil'alamin ${ }^{14}$.

Pesantren as a forum for studying Islamic teachings that are rahmatannlil'alamin (bringing prosperity and mercy to all people and the universe) is very important if religious moderation is included in the learning curriculum at Islamic boarding schools so that it can anticipate the insertion of understanding and practice of extreme and radical religious teachings ${ }^{15}$. both the extreme right and left because of the attitude of radicalism, extremism, and terrorism can divide Muslims, cause

10 Umma Farida, 'Radikalisme, Moderatisme, Dan Liberalisme Pesantren: Melacak Pemikiran Dan Gerakan Keagamaan Pesantren Di Era Globalisasi', Edukasia : Jurnal Penelitian Pendidikan Islam 10, no. 1 (27 March 2015), https://doi.org/10.21043/edukasia.v10i1.789.

11 Muhammad Anas Ma'arif and Nur Silva Nabila, 'The Contribution Of Kiai Munawwar Adnan Kholil Gresik On Islamic Education', Tribakti: Jurnal Pemikiran Keislaman 31, no. 2 (20 July 2020): 218-36, https://doi.org/10.33367/tribakti.v31i2.1126.

12 Laily Fitriani, 'Pendidikan Peace Building Di Pesantren: Sebuah Upaya Mencegah Radikalisasi', ULUL ALBAB Jurnal Studi Islam 16, no. 1 (10 September 2015): 117-30, https://doi.org/10.18860/ua.v16i1.3011.

13 Bernhard Platzdasch and Johan Saravanamuttu, Religious Diversity in Muslim-Majority States in Southeast Asia: Areas of Toleration and Conflict, Religious Diversity in Muslim-Majority States in Southeast Asia (ISEAS Publishing, 2014), https://doi.org/10.1355/9789814519656.

14 Khoirul Anwar, 'Pancasila Village, Multicultural Education and Moderation of Diversity in Indonesia', Nazhruna: Jurnal Pendidikan Islam 4, no. 2 (13 June 2021): 221-34, https://doi.org/10.31538/nzh.v4i2.1238.

15 Ali Imron and Fatah Syukur, 'Religious Moderation in Pesantren Culture Era Post-Truth for SantriCollege Students of Unwahas and UIN Walisongo', Edukasi Islami: Jurnal Pendidikan Islam 10, no. 001 (25 November 2021): 199-218, https://doi.org/10.30868/ei.v10i001.1782. 
conflict and divide the Unitary Republic of Indonesia because of the diversity of races, ethnicities, religions, nations, and customs that exist in Indonesia ${ }^{16}$.

Islamic boarding schools are obliged to be the front fortress to maintain a moderate Islamic religion. The hope of religious moderation carried out in Islamic boarding schools is that a santri (student in Islamic Boarding School) can become an agent of the peace who has a moderate, not extreme, and excessive character in practicing Sharia and Islamic teachings because all religions teach peace and prohibit violence ${ }^{17}$.

The results of Sodikin's research show the application of moderate-based Islamic Education through learning Islamic Religious Education by providing wasatiyah values and strong doctrines of tolerance and mutual respect ${ }^{18}$. While the bearers of strong moderation in Indonesia are institutions under the auspices of NU (Nahdatul Ulama) and Muhammadiyah ${ }^{19}$. The application of character-based moderation in school institutions is carried out through strengthening the values of Aswaja ${ }^{20}$.

Abdurrahman's research resulted in the formation of moderate Muslims in the world of education, teaching materials that are by Islam rahmatan lil Alamin are needed ${ }^{21}$. Teaching materials that include multicultural material, tasamuh, mutual respect and are strongly based on the Qur'an and Hadith. Muhammad Muclis also researched "Moderate Islamic Education in the Frame of Local Wisdom" instilling moderation in students who are integrated with the curriculum, extra-curricular

16 Husnul Khotimah, 'Internalisasi Moderasi Beragama Dalam Kurikulum Pesantren', Rabbani: Jurnal Pendidikan Agama Islam 1, no. 1 (27 January 2020): 62-68, https:/ / doi.org/10.19105/rjpai.v1i1.3008.

17 Irwan Fathurrochman, Dina Hajja Ristianti, and Mohamad Aziz Shah bin Mohamed Arif, 'Revitalization of Islamic Boarding School Management to Foster the Spirit of Islamic Moderation in Indonesia', Jurnal Pendidikan Islam 8, no. 2 (2019): 239-58, https://doi.org/10.14421/jpi.2019.82.239-258.

18 Ahmad Sodikin and Muhammad Anas Ma`arif, 'Penerapan Nilai Islam Moderat Dalam Pembelajaran Pendidikan Agama Islam Di Perguruan Tinggi', EDUKASI: Jurnal Penelitian Pendidikan Agama Dan Keagamaan 19, no. 2 (27 August 2021): 188-203, https://doi.org/10.32729/edukasi.v19i2.702.

19 Zakiyuddin Baidhawy, 'The Muhammadiyah's Promotion of Moderation', American Journal of Islam and Society 32, no. 3 (1 July 2015): 69-91, https://doi.org/10.35632/ajis.v32i3.271; Alexander Raymond Arifianto, 'Islam Nusantara: NU's Bid to Promote “Moderate Indonesian Islam"', Nanyang Technological University, 2016, https://dr.ntu.edu.sg/handle/10356/80647; Toto Suharto, 'Gagasan Pendidikan Muhammadiyah dan NU sebagai Potret Pendidikan Islam Moderat di Indonesia', Islamica: Jurnal Studi Keislaman 9, no. 1 (1 September 2014): 81-109, https:/ / doi.org/10.15642/islamica.2014.9.1.81-109.

20 Ahmad Saefudin and Al Fatihah Al Fatihah, 'Islamic Moderation Through Education Characters of Aswaja An-Nahdliyyah', Nazhruna: Jurnal Pendidikan Islam 3, no. 2 (12 July 2020): 160-79, https://doi.org/10.31538/nzh.v3i2.594.

21 Abdurrohman Abdurrohman and Huldiya Syamsiar, 'Pembelajaran Pendidikan Agama Islam (PAI) Model Keberagamaan Inklusif Untuk Mencegah Radikalisme Beragama Dikalangan Siswa SMA', FENOMENA, 1 June 2017, 105-22, https:/ / doi.org/10.21093/fj.v9i1.789. 
activities, and hidden curriculum and combined with local wisdom of Madurese culture 22 .

Looking at some of the research above, the author makes a difference from previous research and strengthens Hafidz's research on efforts to strengthen moderate values in Islamic Boarding Schools. This article will explain the planning, implementation, and evaluation of moderate values in Islamic boarding schools, while strategies for strengthening moderate values are through the introduction, habituation, example, and experience.

\section{METHOD}

The author uses a qualitative type and what is meant by qualitative research is research whose data results are in the form of written words or speech and behavior of the people observed. By the problems that are the focus of this research, this research belongs to the type of case study research, namely a research strategy that examines in detail a background, one subject, or a particular event.

The location referred to in this study is the Al-Fattah Islamic Boarding School, Siman Village, Sekaran District, Lamongan Regency. Al-Fattah Islamic Boarding School has been established in 1942 and was founded by KH. Abdul Fattah. After KH. Abdul Fattah died caring for the Al-Fattah Islamic Boarding School continued by his sons, namely KH. Abdul Muhith Fattah, KH. Abdul Majid Fattah and KH. Ma'mun Fattah.

In this study, the data sources came from data in the field and written data. Methodologically, there are various data collection techniques that can be used in qualitative research, including 1) Interview, which is conducting face-to-face questions and answers using an interview guide to obtain the desired information.

2) Observation, is collecting data by observing and recording the events or behavior of the object under study. 3) Documentation Study, is collecting data by studying documents or personal records about respondent data. Data analysis according to

22 Mohammad Muchlis Solichin, 'Pendidikan Islam Moderat Dalam Bingkai Kearifan Lokal (Studi Pada Pondok Pesantren Al-Amin Prenduan Sumenep Madura)', Jurnal MUDARRISUNA 8, no. 1 (June 2018): 174-94. 
${ }^{23}$ Miles and Huberman consists of three flows of activities carried out simultaneously, namely data reduction, data display, and verification or conclusion.

\section{RESULTS AND DISCUSSION}

\section{Understanding the Value of Moderation in Islamic Education at Al-Fattah Siman Islamic Boarding School Sekaran Lamongan}

Based on the findings in the research regarding the form of understanding the values of moderation in Islamic education, it was found that the form of understanding the values of moderation in Islamic education is divided into two. That is understanding faith (aqeeda), sharia or worship, and understanding morality.

The principles of faith and sharia or worship held by the Al-Fattah Siman Islamic Boarding School Sekaran Lamongan are based on the principles of creed and fiqh (jurisprudence), the understanding of Ahlussunnah wal Jama'ah, which is based on salaf scholars. Islamic boarding schools instill in students to practice what has been implemented in Islamic boarding schools, both aqeeda based on Imam Asary and fiqh by Imam Syafi'i. Through this, it is hoped that the students will become the next generation of scholars who hold fast to their Aqedah and morals by the values of moderation by the principles of Ahlussunnah wal Jama'ah.

While the form of understanding related to morals that are always emphasized by Islamic boarding schools to students, in general, is tolerance, has a fair nature, prioritizes deliberation, helps, loves peace, upholds etiquette and courtesy.

This is as stated by Afrizal Nur that the characteristics of wasatiyyah are Tawassuț (middle way), Tawāzun (balanced), I"tidal (upright and straight), Tasamuh (tolerant), Musāwāh (equal), Syūrō (consultation), Işlāh (reform), Awlawiyah (priority), and Tathawwur was Ibtikar (dynamic and innovative) ${ }^{24}$.

The Malaysian scholar, Muhammad Kamal Hassan25, gives the notion of wasatiyyat by combining several meanings, namely justice (justice or 'is), good/superior (excellence or khairiyah), and tawazzun or tawassuth, tawazun, and

\footnotetext{
${ }^{23}$ Matthew B. Miles, A. Michael Huberman, and Johnny Saldana, Qualitative Data Analysis: A Methods Sourcebook (SAGE Publications, 2018).

24 Afrizal Nur, 'KONSEP WASATHIYAH DALAM AL-QURAN; (STUDI KOMPARATIF ANTARA TAFSIR AL-TAHRÎR WA AT-TANWÎR DAN AISAR AT-TAFÂSÎR)', Jurnal An-Nur 4, no. 2 (27 September 2016), http:/ / ejournal.uin-suska.ac.id/index.php/Annur/article/view/2062.

${ }^{25}$ Muhammad Haniff Hassan, 'Wasatiyyah as Explained by Prof. Muhammad Kamal Hassan: Justice, Excellence and Balance', International Centre for Political Violence and Terrorism Research 6, no. 2 (2021): 8.
} 
i'tidal). The three elements are markers of Ummatan Wasathan or Khaira Ummah. As for the Malaysian scholar, Hasan Kamali, translating wasatiyyat as a tug-of-war relationship between two paired concepts, such as between ratio and revelation, rights and obligations, individualism and socialism, necessity and volunteerism, ideals and reality, and continuity with change ${ }^{26}$.

The understanding and practice of religious practice of a moderate Muslim have the following characteristics: 1) moderate, namely by taking the middle path, neither right nor left, 2) Tawâzun, a person who has balance in practicing Islamic teachings. The balance between the needs of the world and the obligations towards the hereafter, 3) I'tidal: firm and straight, performing rights and obligations by the rules or proportionally, 4) tolerance/tasamuh: respecting and acknowledging differences that exist both in terms of social or religious aspects, 5) Egalitarian/musâwah does not discriminate against someone due to differences in traditions, and beliefs, 6) Deliberations, 7) Islah (reform), 8) puts priority. 9. Tathawwur was Ibtikar, and 10) civilized ${ }^{27}$.

In terms of Aqedah and fiqh, the adherence of Al-Fattah Siman Sekaran Lamongan Islamic Boarding School to the understanding of Ahlussunnah wal Jama'ah with the concept of rahmatan Lil Alamin through its program of activities or learning confirms its real existence for the application of moderation values. Fattah Siman Sekaran Lamongan reflects on the concept of rahmatan Lil Alamin applied by Nahdlatul Ulama (NU) as the largest moderate religious mass organization in Indonesia 28 .

In line with Abdul Malik Karim Amrullah29, education must formulate a moderate education concept and can be accepted by all circles. Education is not just

26 Wan Norhasniah Wan Husin, 'The Relationship between the Concept of Wasatiyyah and the Values of Budi-Islam in Reinforcing Ethnic Relations in Malaysia', International Journal of Social Science and Humanity, 2013, 528-31, https:/ / doi.org/10.7763/IJSSH.2013.V3.297.

27 Faris Khoirul Anam, Moh Padil, and Mokhammad Yahya, 'Building Ahlus-Sunnah Wal-Jamaah anNahdliyah Character as the Pillar of Islamic Moderation in Islamic Boarding School', Buletin Al-Turas 27, no. 2 (31 July 2021): 249-64, https://doi.org/10.15408/bat.v27i2.20062.

28 Masdar Hilmy, 'Whither Indonesias Islamic Moderatism? A Reexamination on the Moderate Vision of Muhammadiyah and $\mathrm{Nu}^{\prime}$, JOURNAL OF INDONESIAN ISLAM 7, no. 1 (1 June 2013): 24-48, https://doi.org/10.15642/JIIS.2013.7.1.24-48.

${ }_{29}$ Muhammad Arkhanul Khamsi and Nur Asiah, 'Pemikiran Pendidikan Islam Kontemporer Menurut Haji Abdul Malik Karim Amrullah (Hamka)', Arfannur 2, no. 2 (23 December 2021): 145-56, https://doi.org/10.24260/arfannur.v2i2.462. 
a concept but must be applied at the institutional level through programs, learning model approaches that are used to save human nature.

The implementation of moderation values is in accordance with the teachings of Ahlussunnah wal Jama'ah which emphasizes the importance of tolerance and peace in preaching as the kyai hopes for the next generation, namely the santri (student in Boarding School). The values of moderation in Islamic education cannot be separated from the teachings of Ahlussunnah wal Jama'ah in the faith which recognizes four schools of jurisprudence, namely Hanafi, Maliki, Shafi'i, and Hanafi. While in the field of Sufism, Following Imam Al-Ghazali, Imam Junaid AlBaghdadi, and other priests. The understanding of morality in the application of moderation values does not only emphasize the human relationship to God but also the human relationship with fellow human beings. So that the books taught in Islamic boarding schools are also books written by salaf scholars which are in accordance with the understanding of Ahlussunnah wal Jama'ah.

This is by what was conveyed by M. Quraish Shihab that the teachings of Islam are summarized in three main things, namely Aqedah, sharia or ubudiyyah, and character or morals so that when the values of moderation are reflected in these three things, the human will become khayra ummah (the best people) ${ }^{30}$.

With some of the results of the analysis, the author concludes that the understanding of moderate values in Islamic education at the Al-Fattah Siman Islamic Boarding School Sekaran Lamongan is in accordance with the theory presented both in the field of Aqedah, sharia or worship and in the field of morals.

Implementation of Moderation Values in Islamic Education at Al-Fattah Siman Islamic Boarding School Sekaran Lamongan

There are three stages in the process of implementing the value of moderation in Islamic education at the Al-Fattah Siman Islamic Boarding School Sekaran Lamongan, namely planning, implementation and evaluation. The explanation of these stages is as follows.

\section{Moderation Education Planning}

Based on the results of the existing research, a plan for implementing an activity program was prepared and formulated by involving caregivers,

${ }^{30}$ M. Quraish Shihab, Rasionalitas Al-Qur'an: Studi Kritis atas Tafsir Al-Manar (Lentera Hati, 2006). 
administrators, the council of teachers, and community leaders. Planning for the implementation of the values of moderation begins with the selection of new students, the selection of teachers' acceptance, the determination of the books to be taught, and the formulation of the program of activities in the pesantren.

Learning planning is important based on the following: 1) the learning process is an activity that has a purpose. To achieve this goal, lecturers need to formulate/design a lesson plan at the beginning of the activity. 2) the learning process is an interactive activity between lecturers and students. In the learning process, student participation is important. Teachers cannot carry out the learning process and achieve learning objectives without the involvement of students. To get optimal participation from students, lecturers must design a lesson plan to develop cognitive, affective, and psychomotor aspects. 3) the learning process is not just a transmission of knowledge but is a formation of student attitudes, behaviors, and skills. This collaborative process must involve various learning components such as educators, students, media, and learning resources, all of which must be planned properly ${ }^{31}$.

The research findings are by what is explained by Ansong that the planning system in education is very necessary for communication-related to decision making, planning, monitoring, evaluating, and formulating policies that need communication as supporting material in educational planning. ${ }^{32}$

\section{Application of Moderation Education}

There are three kinds of implementation of Moderation Values in Islamic Education at Al-Fattah Siman Islamic Boarding School Sekaran Lamongan, namely through teaching and learning activities in the classroom, religious-spiritual activities, and skills supporting activities or extracurricular. Without implementation through teaching and learning in the classroom, religious-spiritual activities, and skills or extracurricular activities, the implementation of moderation values in Islamic education is only a meaningless discourse.

31 Mohammad Muchlis Solichin, 'Manajemen Pembelajaran Pendidikan Islam Moderat Di Perguruan Tinggi Islam (studi Atas Institute Agama Islam Negeri Madura)', re-JIEM (Research Journal of Islamic Education Management) 1, no. 2 (2018): 60-69, https://doi.org/10.19105/re-jiem.v1i2.2091.

32 J. Ansong, E. Gissi, and H. Calado, 'An Approach to Ecosystem-Based Management in Maritime Spatial Planning Process', Ocean $\mathcal{E}$ Coastal Management 141 (1 June 2017): 65-81, https://doi.org/10.1016/j.ocecoaman.2017.03.005. 
From the three forms of implementation above, there are three kinds of values of Islamic moderation in this study. The moderate values of Islam are Is (justice), tawazun (balance), and tasamuh (tolerance). These values are sourced from religious teachings and if the author examines them more deeply, these values are classified as divine and human values. This is in Zayadi's opinion quoted by Abdul Majid and Dian Andayani that the values that apply in life are grouped into two types, namely Divine and Insaniyah values ${ }^{33}$. And what is included in the divine values are tawazun, while those included in the human values are tasamuh. The explanation of the three forms of activities related to the implementation of moderation values in Islamic education at the Al-Fattah Siman Islamic Boarding School Sekaran Lamongan is as follows ${ }^{34}$.

Meanwhile, the moderation reinforcement follows the model of Faris Khoirul Anam et al, namely the sources of material development and Islamic moderation curriculum in Islamic boarding schools, namely (1) Islamic moderation guards; (2) maintain togetherness; (3) recognize the authority of the fiqh school; (4) acknowledge the existence of heresy hasanah; (5) loyal opposition to the authorities; (6) methodological (manhaji) is not liberal; (7) does not hegemony the truth; (8) respecting local wisdom with ushul figh standards. This research is expected to be able to contribute to realizing the spirit of religious moderation in Indonesia ${ }^{35}$.

\section{Moderation Learning Activities}

The process of implementing teaching and learning activities in the classroom is the process of implementing the value of (fairness) which is included in the values of moderation, namely that the teachers are fair to all students, regardless of the background of the students. The teachers pressure the students to be fair, namely fair to Allah SWT, fair to themselves, namely by always maintaining a good attitude. Fair to others, namely treating others according to what is their right and not to hurt them. Fair to other living things, namely maintaining and protecting the environment and nature. All of that is done in the teaching and learning process.

33 Abdul Majid, Pendidikan agama Islam berbasis kompetensi: konsep dan implementasi kurikulum 2004 (Remaja Rosdakarya, 2004).

34 Ilyya Muhsin, Nikmah Rochmawati, and Muhammad Chairul Huda, 'Revolution of Islamic Proselytizing Organization: From Islamism to Moderate', QIJIS (Qudus International Journal of Islamic Studies) 7, no. 1 (3 June 2019): 45-70, https:/ / doi.org/10.21043/qijis.v7i1.5076.

35 Anam, Padil, and Yahya, 'Building Ahlus-Sunnah Wal-Jamaah an-Nahdliyah Character as the Pillar of Islamic Moderation in Islamic Boarding School'. 
The teacher provides opportunities for all students to participate in teaching and learning activities and when in the learning process students gain the right to acquire knowledge and are required to carry out their obligations as a student in accordance with the regulations in the Pesantren.

In implementing the values of moderation in Islamic education at the AlFattah Siman Sekaran Lamongan Islamic Boarding School in the next teaching and learning process is tasamuh (tolerance), the form of activity is with deliberation activities or group discussions, study together, group cooperation, the election of class leaders, selection of room leaders, division of picket groups, and making rules in classes and rooms.

The process of implementing moderate values in Islamic education at the AlFattah Siman Islamic Boarding School Sekaran Lamongan in religious spiritual activities is to apply the value of Is (justice). When students carry out religious spiritual activities, students reflect on the nature of justice, students are not only preoccupied with learning religious knowledge but also get closer to God for example, such as praying in congregation, reading wirid, and other religious activities.

The strategy of delivering learning also cannot be separated from two approaches, namely teacher-centered and student-centered. Teacher-centered teaching includes several teaching strategies in which the teacher is tasked with presenting the knowledge to be learned and explicitly guiding the student learning process. Whereas student-centered teaching, students have more responsibilities in constructing their knowledge, the teacher's job is only as a guide ${ }^{36}$.

\section{Skills Supporting Activities or Extracurricular}

The next Islamic moderation values that are implemented are the values of tawazun (balance). At the Al-Fattah Siman, Islamic Boarding School Sekaran Lamongan in implementing the value of tawazun is through Skills Support Activities or Extracurricular. This is intended to maintain balance in all respects, students are not only equipped with religious knowledge but also skills that will later be useful

\footnotetext{
36 John Nisbet and Janet Shucksmith, Learning Strategies (Routledge, 2017); Felicitas Biwer et al., 'Fostering Effective Learning Strategies in Higher Education - A Mixed-Methods Study', Journal of Applied Research in Memory and Cognition 9, no. 2 (1 June 2020): 186-203, https://doi.org/10.1016/j.jarmac.2020.03.004.
} 
for students in interacting with the wider community in their lives. So, it is clear that the effort to instill the value of tawazun is to realize a balanced santri in both worldly and hereafter affairs.

In implementing the values of moderation in Islamic education at the AlFattah Siman Islamic Boarding School Sekaran Lamongan, the teacher has several strategies so that the values of moderation can be implemented properly, because implementing the values of moderation to students requires cooperation between various parties, both by teachers, administrators, and caretakers of Islamic boarding schools. In the findings of the data obtained by the researchers, the strategies used by the teachers in implementing the values of moderation are as follows.

Introduction: At this stage, to implement the values of moderation for students, an understanding of the values of Islamic teachings, including the values of moderation, is given. This is done during teaching and learning activities and during skills support activities. For example, through lectures during khitobiyah (learn speech), yasinan or tahlilan activities.

Habituation: The values that exist in the santri must be familiarized with activities that are routinely carried out in the pesantren because everything that is used to be done will be internalized and absorbed within them will raise selfawareness about the importance of these values in everyday life. Activities carried out repeatedly will become habits and become religious activities, and that will have an impact on instilling a value. At Pondok Pesantren Al-Fattah Siman Sekaran Lamongan, one of the strategies for internalizing the value of Islamic moderation is through the habituation method, the goal is for students to feel they have the value of moderation and are aware of the importance of the value of moderation in life. As for the habituation, such as congregational prayers, istighasah, and ro'an (service work).

Exemplary: When the values of moderation have been accepted and loved by the students, it is necessary to have real examples from the teachers so that the students can see a real picture of a value that is exemplified by the teachers. Exemplary is one of the effective ways in the process of implementing value in students. This is because the teachers are the most obvious examples to be imitated and imitated by the students in all their behavior and speech. At the Al-Fattah 
Siman Islamic Boarding School Sekaran Lamongan, the teachers exemplified the value of Islamic moderation by being punctual, tolerant, fair to all students, resolving problems by way of deliberation, and respecting and respecting differences.

Practice: The values already owned by students will be seen if these values are practiced in everyday life without any orders and coercion. If that has been done, the students have formed a personality from these values. As at the Al-Fattah Siman Islamic Boarding School Sekaran Lamongan, the students are automatically used to worshiping without being ordered to, carrying out religious activities such as istigasah also on time without being ordered by the teachers, besides that, the concern for students is also very high, such as cleaning the Pesantren environment, helping friends who need help. difficulties, respecting and respecting differences when there are friends who have different opinions in class discussions, and being respectful and polite to friends and other Pesantren residents.

From the explanation above, it can be concluded that the strategy for implementing the values of moderation begins with the introduction of good and bad moderation values, then these values are lived through habituation with religious activities, then these activities are accustomed to in everyday life, and to find out that these values have been integrated into the students, it can be seen from the values of moderation which are implemented every day without any orders or coercion.

In the stage of implementing moderate values in Islamic education at the AlFattah Siman Islamic Boarding School Sekaran Lamongan after the planning and implementation stages, the last stage is evaluation. Based on the results of existing research regarding the evaluation of the process of implementing the values of moderation, it is divided into three types, namely program evaluation, evaluation of the learning process, and evaluation of learning outcomes. Evaluation of the activity program is carried out once a semester by involving caregivers, administrators, and the teacher's board, while the evaluation of the learning process is carried out once a month to control or determine the ability of students related to material or religious understanding and their activities. The third is the evaluation of learning outcomes carried out twice a year which is called the initial imtihan and imtihanul nihaiyyah. 
This evaluation is used to evaluate the level of students' ability to understand and practice the knowledge gained.

In the context of learning IRE material with a moderate perspective, learning outcomes can be measured by the ability of students to understand and apply moderate values, including being able to learn to live in differences with all students from different cultural, ethnic, and ethnic backgrounds, social status in school and in the community, build mutual trust between students and multicultural communities, maintain mutual understanding with students and multicultural communities uphold mutual respect for differences of opinion and religious beliefs, think openly, resolve conflicts and reconciliation without violence, such as being able to solve problems at school by prioritizing dialogical deliberation among friends ${ }^{37}$.

\section{CONCLUSION}

The process of understanding the values of moderation in Islamic education at the Al-Fattah Siman Islamic Boarding School Sekaran Lamongan is the basis for the formation of the character of the santri who in practice adheres to the principles of Ahlussunnah waljama'ah understanding with a tendency to moderation or wasatiyyah through understanding aqidah, sharia or worship, and morality. The process of implementing the values of moderation in Islamic education at the AlFattah Siman Islamic Boarding School now in Lamongan is carried out in several stages, namely planning, implementation and evaluation. Planning includes selection tests for acceptance of students, administrators, and teachers as well as the preparation of programs that involve caregivers, administrators, and teachers. In practice, the process of implementing moderate values in Islamic education at the Al-Fattah Siman Islamic Boarding School Sekaran Lamongan is applied to three activities, namely teaching and learning activities, religious-spiritual activities, and skills supporting activities. Implementing the values of moderation in Islamic education at the Al-Fattah Siman Islamic Boarding School Sekaran Sekaran Lamongan uses four strategies: introduction, habituation, example, and practice. Meanwhile, for the evaluation stage of the implementation of moderation values in

\footnotetext{
${ }^{37}$ Muchlis Muchlis, 'Pembelajaran Materi Pendidikan Agama Islam (PAI) Berwawasan Moderat', Profetika: Jurnal Studi Islam 21, no. 1 (5 June 2020): 11-20, https://doi.org/10.23917/profetika.v21i1.11053.
}

34| Vol. 3, No.1, January 2022 
Islamic education at the Al-Fattah Siman Islamic Boarding School now Lamongan, it is divided into three forms, namely program evaluation, evaluation of the learning process, and evaluation of learning outcomes.

\section{REFERENCES}

Abdurrohman, Abdurrohman, and Huldiya Syamsiar. 'Pembelajaran Pendidikan Agama Islam (PAI) Model Keberagamaan Inklusif Untuk Mencegah Radikalisme Beragama Dikalangan Siswa SMA'. FENOMENA, 1 June 2017, 105-22. https:// doi.org/10.21093/fj.v9i1.789.

Adi, Agus, Maya Sari, and Rr Setyowati. 'Radicalism and Political Indentity in Indonesia President Election 2019', 411-16. Atlantis Press, 2019. https://doi.org/10.2991/icss-19.2019.161.

Anam, Faris Khoirul, Moh Padil, and Mokhammad Yahya. 'Building Ahlus-Sunnah Wal-Jamaah an-Nahdliyah Character as the Pillar of Islamic Moderation in Islamic Boarding School'. Buletin Al-Turas 27, no. 2 (31 July 2021): 249-64. https://doi.org/10.15408/bat.v27i2.20062.

Ansong, J., E. Gissi, and H. Calado. 'An Approach to Ecosystem-Based Management in Maritime Spatial Planning Process'. Ocean \& Coastal Management 141 (1 June 2017): 65-81. https:/ / doi.org/10.1016/j.ocecoaman.2017.03.005.

Anwar, Khoirul. 'Pancasila Village, Multicultural Education and Moderation of Diversity in Indonesia'. Nazhruna: Jurnal Pendidikan Islam 4, no. 2 (13 June 2021): 221-34. https:/ / doi.org/10.31538/nzh.v4i2.1238.

Arifianto, Alexander Raymond. 'Islam Nusantara: NU's Bid to Promote "Moderate Indonesian Islam"'. Nanyang Technological University, 2016. https://dr.ntu.edu.sg/handle/10356/80647.

Arifin, M. Ilmu Pendidikan Islam: Suatu Tinjauan Teoritis dan Praktis Berdasarkan Pendekatan Interdisipliner. Bumi Aksara, 1991.

Aspinall, Edward, and Marcus Mietzner. 'Southeast Asia's Troubling Elections: Nondemocratic Pluralism in Indonesia'. Journal of Democracy 30, no. 4 (2019): 104-18. https:// doi.org/10.1353/jod.2019.0055. 
Baidhawy, Zakiyuddin. 'The Muhammadiyah's Promotion of Moderation'. American Journal of Islam and Society 32, no. 3 (1 July 2015): 69-91. https://doi.org/10.35632/ajis.v32i3.271.

Biwer, Felicitas, Mirjam G. A. oude Egbrink, Pauline Aalten, and Anique B. H. de Bruin. 'Fostering Effective Learning Strategies in Higher Education - A Mixed-Methods Study'. Journal of Applied Research in Memory and Cognition 9, no. 2 (1 June 2020): 186-203. https:// doi.org/10.1016/j.jarmac.2020.03.004.

Farida, Umma. 'Radikalisme, Moderatisme, Dan Liberalisme Pesantren: Melacak Pemikiran Dan Gerakan Keagamaan Pesantren Di Era Globalisasi'. Edukasia : Jurnal Penelitian Pendidikan Islam 10, no. 1 (27 March 2015). https://doi.org/10.21043/edukasia.v10i1.789.

Fathurrochman, Irwan, Dina Hajja Ristianti, and Mohamad Aziz Shah bin Mohamed Arif. 'Revitalization of Islamic Boarding School Management to Foster the Spirit of Islamic Moderation in Indonesia'. Jurnal Pendidikan Islam 8, no. 2 (2019): 239-58. https:/ / doi.org/10.14421/jpi.2019.82.239-258.

Fitriani, Laily. 'Pendidikan Peace Building Di Pesantren: Sebuah Upaya Mencegah Radikalisasi'. ULUL ALBAB Jurnal Studi Islam 16, no. 1 (10 September 2015): 117-30. https:// doi.org/10.18860/ua.v16i1.3011.

Hassan, Muhammad Haniff. 'Wasatiyyah as Explained by Prof. Muhammad Kamal Hassan: Justice, Excellence and Balance'. International Centre for Political Violence and Terrorism Research 6, no. 2 (2021): 8.

Hefner, Robert W. 'Islamic Radicalism in a Democratizing Indonesia'. In Routledge Handbook of Political Islam. Routledge, 2011.

Hilmy, Masdar. 'Whither Indonesias Islamic Moderatism? A Reexamination on the Moderate Vision of Muhammadiyah and Nu'. JOURNAL OF INDONESIAN ISLAM 7, no. 1 (1 June 2013): 24-48. https://doi.org/10.15642/JIIS.2013.7.1.24-48.

Husin, Wan Norhasniah Wan. 'The Relationship between the Concept of Wasatiyyah and the Values of Budi-Islam in Reinforcing Ethnic Relations in Malaysia'. International Journal of Social Science and Humanity, 2013, 528-31. https:/ / doi.org/10.7763/IJSSH.2013.V3.297. 
Ibrahim, Mazlan, Jaffary Awang, Latifah Abdul Majid, Haziyah Husin, Muhd Najib Abdul Kadir, Abur Hamdi Usman, and Latifah Abdul Majid. 'Wasatiyyah Discourse According to Muslim Scholars in Malaysia', 2013, 9.

Imron, Ali, and Fatah Syukur. 'Religious Moderation in Pesantren Culture Era PostTruth for Santri-College Students of Unwahas and UIN Walisongo'. Edukasi Islami: Jurnal Pendidikan Islam 10, no. 001 (25 November 2021): 199-218. https://doi.org/10.30868/ei.v10i001.1782.

Khamsi, Muhammad Arkhanul, and Nur Asiah. 'Pemikiran Pendidikan Islam Kontemporer Menurut Haji Abdul Malik Karim Amrullah (Hamka)'. Arfannur 2, no. 2 (23 December 2021): 145-56. https://doi.org/10.24260/arfannur.v2i2.462.

Khotimah, Husnul. 'Internalisasi Moderasi Beragama Dalam Kurikulum Pesantren'. Rabbani: Jurnal Pendidikan Agama Islam 1, no. 1 (27 January 2020): 62-68. https:// doi.org/10.19105/rjpai.v1i1.3008.

Levin, Brian, and John David Reitzel. 'Report to the Nation: Hate Crimes Rise in U.S. Cities and Counties in Time of Division and Foreign Interference', 2018. https://ncvc.dspacedirect.org/handle/20.500.11990/975.

Ma'arif, Muhammad Anas, and Nur Silva Nabila. 'The Contribution Of Kiai Munawwar Adnan Kholil Gresik On Islamic Education'. Tribakti: Jurnal Pemikiran Keislaman 31, no. 2 (20 July 2020): 218-36. https://doi.org/10.33367/tribakti.v31i2.1126.

Majid, Abdul. Pendidikan agama Islam berbasis kompetensi: konsep dan implementasi kurikulum 2004. Remaja Rosdakarya, 2004.

Malik, Abdul, Ajat Sudrajat, and Farida Hanum. 'Kultur Pendidikan Pesantren Dan Radikalisme'. Jurnal Pembangunan Pendidikan: Fondasi dan Aplikasi 4, no. 2 (2016): 103-14. https:// doi.org/10.21831/jppfa.v4i2.11279.

Miles, Matthew B., A. Michael Huberman, and Johnny Saldana. Qualitative Data Analysis: A Methods Sourcebook. SAGE Publications, 2018.

Muchlis, Muchlis. 'Pembelajaran Materi Pendidikan Agama Islam (PAI) Berwawasan Moderat'. Profetika: Jurnal Studi Islam 21, no. 1 (5 June 2020): 1120. https://doi.org/10.23917/profetika.v21i1.11053. 
Muchlis Solichin, Mohammad. ‘Pendidikan Islam Moderat Dalam Bingkai Kearifan Lokal (Studi Pada Pondok Pesantren Al-Amin Prenduan Sumenep Madura)'. Jurnal MUDARRISUNA 8, no. 1 (June 2018): 174-94.

Muhsin, Ilyya, Nikmah Rochmawati, and Muhammad Chairul Huda. 'Revolution of Islamic Proselytizing Organization: From Islamism to Moderate'. QIJIS (Qudus International Journal of Islamic Studies) 7, no. 1 (3 June 2019): 45-70. https://doi.org/10.21043/qijis.v7i1.5076.

Mujani, Wan Kamal, Ermy Azziaty Rozali, and Nor Jamaniah Zakaria. 'The Wasatiyyah (Moderation) Concept: Its Implementation In Malaysia'. Mediterranean Journal of Social Sciences, 1 July 2015. https://doi.org/10.5901/mjss.2015.v6n4s2p66.

Nisbet, John, and Janet Shucksmith. Learning Strategies. Routledge, 2017.

Nur, Afrizal. 'KONSEP WASATHIYAH DALAM AL-QURAN; (STUDI KOMPARATIF ANTARA TAFSIR AL-TAHRÎR WA AT-TANWÎR DAN AISAR AT-TAFÂSÎR)'. Jurnal An-Nur 4, no. 2 (27 September 2016). http:// ejournal.uin-suska.ac.id/index.php/Annur/article/view/2062.

Nur, Iffatin, A. Hasyim Nawawie, Hiba Fajarwati, and Hani Chusna. 'Embracing Radicalism and Extremism in Indonesia with the Beauty of Islam'. Asian Research Journal of Arts \& Social Sciences, 31 January 2020, 1-18. https://doi.org/10.9734/arjass/2020/v10i230141.

Nurdin, Fauziah. 'Moderasi Beragama menurut Al-Qur'an dan Hadist'. Jurnal Ilmiah Al-Mu'ashirah: Media Kajian Al-Qur'an dan Al-Hadits Multi Perspektif 18, no. 1 (30 January 2021): 59-70. https://doi.org/10.22373/jim.v18i1.10525.

Platzdasch, Bernhard, and Johan Saravanamuttu. Religious Diversity in MuslimMajority States in Southeast Asia: Areas of Toleration and Conflict. Religious Diversity in Muslim-Majority States in Southeast Asia. ISEAS Publishing, 2014. https://doi.org/10.1355/9789814519656.

Saefudin, Ahmad, and Al Fatihah Al Fatihah. 'Islamic Moderation Through Education Characters of Aswaja An-Nahdliyyah'. Nazhruna: Jurnal Pendidikan Islam 3, no. 2 (12 July 2020): 160-79. https:// doi.org/10.31538/nzh.v3i2.594. 
Shihab, M. Quraish. Rasionalitas Al-Qur'an: Studi Kritis atas Tafsir Al-Manar. Lentera Hati, 2006.

Sodikin, Ahmad, and Muhammad Anas Ma`arif. ‘Penerapan Nilai Islam Moderat Dalam Pembelajaran Pendidikan Agama Islam Di Perguruan Tinggi'. EDUKASI: Jurnal Penelitian Pendidikan Agama Dan Keagamaan 19, no. 2 (27 August 2021): 188-203. https://doi.org/10.32729/edukasi.v19i2.702.

Solichin, Mohammad Muchlis. 'Manajemen Pembelajaran Pendidikan Islam Moderat Di Perguruan Tinggi Islam (studi Atas Institute Agama Islam Negeri Madura)'. re-JIEM (Research Journal of Islamic Education Management) 1, no. 2 (2018): 60-69. https:// doi.org/10.19105/re-jiem.v1i2.2091.

Suharto, Toto. 'Gagasan Pendidikan Muhammadiyah dan NU sebagai Potret Pendidikan Islam Moderat di Indonesia'. Islamica: Jurnal Studi Keislaman 9, no. $1 \quad$ (1 1 September https:// doi.org/10.15642/islamica.2014.9.1.81-109.

Yanti, Betria Zarpina, and Doli Witro. 'Islamic Moderation as A Resolution of Different Conflicts of Religion'. Andragogi: Jurnal Diklat Teknis Pendidikan Dan Keagamaan 8, no. 1 (16 July 2020): 446-57. https://doi.org/10.36052/andragogi.v8i1.127.

Yumnah, Siti. 'Construction of Islamic Boarding Shcool in Developing Moderate Islam'. Nazhruna: Jurnal Pendidikan Islam 3, no. 2 (24 July 2020): 232-46. https://doi.org/10.31538/nzh.v3i2.614. 